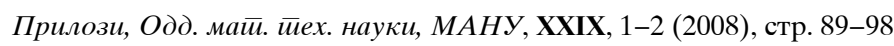
Contributions, Sec. Math. Tech. Sci., MANU, XXIX, 1-2 (2008), pp. 89-98

ISSN 0351-3246

UDC: $667.281: 543.544 .5$

\title{
HPLC INVESTIGATION OF THE DEGRADATION OF SOME ARTIFICIAL AZO FOOD COLORANTS IN THE PRESENCE OF ASCORBIC ACID
}

\author{
Vesna Kostić, Trajče Stafilov, Kiro Stojanoski
}

\begin{abstract}
A b s tract: The influence of the concentration of ascorbic acid on some azo food colorant (Brilliant Black BN, Brilliant Blue FCF, Chinoline Yellow, Indigotine, Patent Blue V and Tartazine) degradation in the solution has been studied. Rate constant $(k)$, time of colorant half-life $\left(t_{1 / 2}\right)$, as well as the type of the kinetic reaction have been determined. The colorants and the ascorbic acid have been determined by high performance liquid chromatography (HPLC) with diode array detector (DAD) and UV-VIS spectrometry. It was found that the higher concentration of ascorbic acid leads to the higher rate constant and lower colorants half-life. The values of the rate constants are 2.50-4.25 times higher when the colorant degradation was run in the presence of $500 \mathrm{mg} \mathrm{L}^{-1}$ of ascorbic acid than in the case of the presence of $100 \mathrm{mg} \mathrm{L}^{-1}$ ascorbic acid for Brilliant Blue FCF, Chinoline Yellow, Patent Blue V and Tartazine. From the other side, the degradation of Brilliant Black BN and Indigotine is very fast with a total degradation for 6-9 days. Therefore, the rate constants for those two food colorants are much higher than for the other investigated colorants. According to the linearity of the kinetics curves $\left(\ln \left(c / c_{0}\right)\right.$ v.s. time $)$ it appeared to be first order kinetics for the interval up to 4 days.
\end{abstract}

Key words: Food Colorants; Brilliant Black BN; Brilliant Blue FCF; Chinoline Yellow; Indigotine; Patent Blue V; Tartazine; ascorbic acid; degradation; kinetics rate constant; HPLC; UV-VIS spectrometry 


\section{INTRODUCTION}

The artificial food colorants are widely used in food industry, for coloring foodstuff matter, but in fact they have no any nutritional value. The use of particular food colorant in food industry depends primarily of its toxicity. However, at the same time, of major importance are also some other factors such as stability of the colorant used for coloring certain food product and whether there is a possible interaction between some component of the foodstuff matter and the colorant. There are several papers concern on the stability of some of the investigated colorants using different reducing agents or factors: by inorganic oxysulfur compounds [1], $\mathrm{pH}$ [2], microflora [3] or temperature [4]. Some reducing agents present in the food may react especially with azo dyes forming degradation products, which may react further with other food components forming undesirable compounds [5-13]. One of the agents, which can react with these dyes causing their degradation, is ascorbic acid [14-17]. The ascorbic acid is often used in the soft drinks as a nutritional supplement or as an antioxidant and provides a reducing environment in which azo dyes can easily be degraded. In real food, the sucrose, known as a stabilizer of ascorbic acid [14], is also present. These facts make the field of investigation of degradation of colorants used in food industry very actual.

In our previous paper [17] we presented data about degradation investigations of artificial food colorants with naphtalenic structure (Ponceau 4R, Amaranth, Allura Red, Brilliant Black BN, Carmoisine and Sunset Yellow) in the presence of ascorbic acid. In the present study, the influence of the concentration of ascorbic acid on the stability of some other azo dyes (Brilliant Blue BN, Brilliant Blue FCF, Chinoline Yellow, Indigotine, Patent Blue V, Tartazine), Fig. 1, has been presented. Rate constant $(k)$, time of colorant half-life $\left(t_{1 / 2}\right)$, as well as the type of the kinetic reaction have been determined. At the same time, degradation of ascorbic acid in the solutions has been also followed.

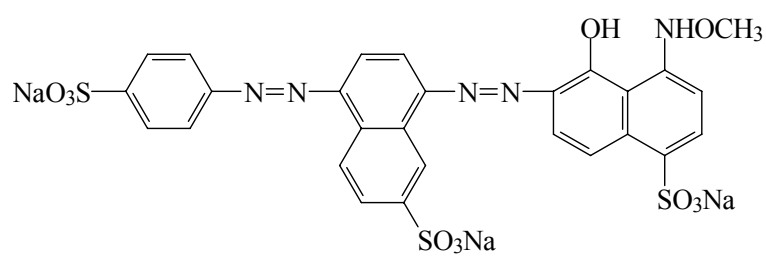

Brilliant Blue BN

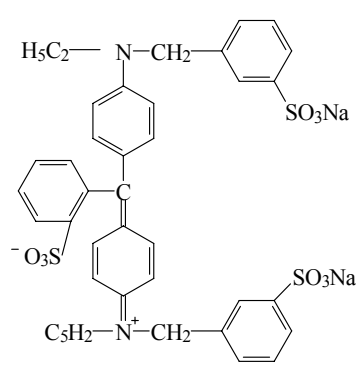

Brilliant Blue FCF 


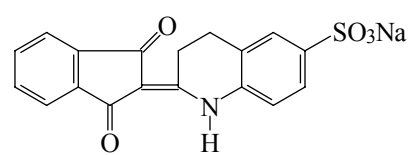

Chinoline Yellow (I)

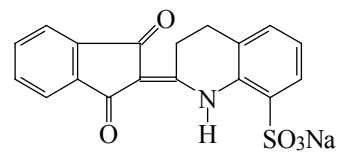

Chinoline Yellow (II)

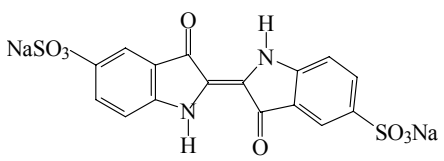

Indigotine

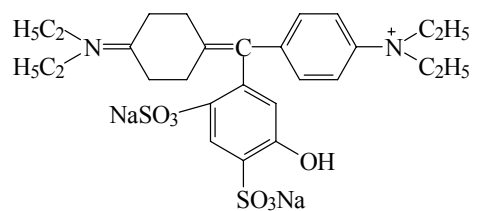

Patent Blue V

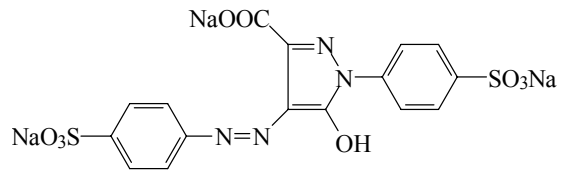

Tartazine

Fig. 1. Structural formulas of the investigated food colorants

\section{EXPERIMENTAL}

\section{Instrumental}

HPLC system Perkin-Elmer (Perkin-Elmer, USA) equipped with Diode Array Detector 235 C, and binary pump series 200 have been used.

UV-VIS Spectrophotometer, model Milton Roy (Milton Roy, France).

Liquid chromatography column was used. Stainless steel $10 \mathrm{~cm}$ long and $4.6 \mathrm{~mm}$ inside diameter, packed with $5 \mu \mathrm{m}$ Pecosphere $\mathrm{C} 18$, was used (Merck, Germany).

\section{Reagents}

Mobile phase was composed of solvent A $\left(0.01 \mathrm{~mol} \mathrm{~L}^{-1} \mathrm{KH}_{2} \mathrm{PO}_{4}\right.$ adjusted to $\mathrm{pH} 4.5$ with $o$-phosphoric acid) and solvent B (methanol HPLC grade, Merck, Germany).

Acetate buffer $(\mathrm{pH}=5.5)$ was prepared by dissolving $6.8 \mathrm{~g}$ of sodium acetate, adjusted with acetic acid in $1 \mathrm{~L}$.

Reference food colorant standards were obtained from Etol (Slovenia) and Wurth (Austria). 


\section{Methods}

The model solutions containing investigated dyes were made in acetate buffer $(\mathrm{pH}=5.5)$. Concentration of added dyes in model solutions was $40 \mathrm{mg} \mathrm{L}^{-1}$, and concentrations of the ascorbic acid were 100,250 and $500 \mathrm{mg} \mathrm{L}^{-1}$. The dissolved oxygen was removed from solutions by purging of helium.

The solutions were kept in dark at room temperature. The degree of degradation of ascorbic acid and food colorants was monitored within 4 weeks. The rate of ascorbic acid degradation was monitored by HPLC, and the rate of food colorant degradation was monitored simultaneously by HPLC and by visible spectrometry [18].

Gradient profile used for all colorants (except eritrozine) was as follows: 3 minutes $100 \% \mathrm{~A}, 0-100 \% \mathrm{~B}$ in $4 \mathrm{~min}$, held at $100 \% \mathrm{~B}$ for $8 \mathrm{~min}$, returned to $100 \% \mathrm{~A}$ and held $10 \mathrm{~min}$ before next injection. Gradient profile for eritrozine was: 2 minutes $100 \%$ A, $0-100 \%$ B in $1 \mathrm{~min}, 30-50 \%$ B for 1 $\min , 70-100 \% \mathrm{~B}$ for $1 \mathrm{~min}$, held at $100 \% \mathrm{~B}$ for $9 \mathrm{~min}$, returned to $100 \% \mathrm{~A}$ and held $10 \mathrm{~min}$ before next injection.

HPLC determination of ascorbic acid was performed at $255 \mathrm{~nm}$. Wavelengths for HPLC and spectrometric determination of artificial food colorants are given in Table 1 .

$\mathrm{T}$ a b 1 e 1

Wavelengths for determinations of some synthetic food colorants

\begin{tabular}{lccccc}
\hline \hline Synthetic food colorant & EEC & Coloring & Chemical & \multicolumn{2}{c}{ Wavelength, nm } \\
& serial No & Index No & Abstracts No & HPLC & Vis spectrophotometry \\
\hline Brilliant Black BN & E 151 & 28440 & $2519-30-4$ & 220 & 568 \\
Brilliant Blue FCF & E 133 & 42090 & $2650-18-2$ & 220 & 630 \\
Chinoline Yellow & E 104 & 47005 & $8004-92-0$ & 245 & 414 \\
Indigotine & E 132 & 73015 & $860-22-0$ & 245 & 615 \\
Patent Blue V & E 131 & 42051 & $129-17-9$ & 210 & 638 \\
Tartazine & E 102 & 19140 & $1934-21-0$ & 255 & 427 \\
\hline
\end{tabular}




\section{RESULTS AND DISCUSSION}

In our previous investigation [17] we found that the presence of ascorbic acid influences the degradation of the food colorants with naphtalenic structure (Ponceau 4R, Amaranth, Allura Red, Carmoisine and Sunset Yellow). In this paper, the influence of the ascorbic acid on the degradation of other azo food colorant (Brilliant Black BN, Brilliant Blue FCF, Chinoline Yellow, Indigotine, Patent Blue V, Tartazine) was studied.

The rate of degradation of the investigated food colorants was studied in the presence of ascorbic acid with different concentration (100, 250 and 500 $\left.\mathrm{mg} \mathrm{L}^{-1}\right)$. The model solutions were previously preserved by adding of potassium sorbate $\left(48 \mathrm{mg} \mathrm{L}^{-1}\right)$. The concentration of all added dyes was $40 \mathrm{mg} \mathrm{L}^{-1}$, because this concentration appeared to be most likely used in the preparation of soft drinks. The ascorbic acid is very rapidly oxidized by dissolved molecular oxygen in the model solutions. In order to decrease the degradation of ascorbic acid oxygen was removed from the solution by purged the samples by helium instead nitrogen proposed by other authors [19]. The colorants and the ascorbic acid have been determined by high performance liquid chromatography (HPLC) with diode array detector (DAD) and UV-VIS spectrometry.

From the obtained results (Fig. 2, Table 2) it can be seen that the rate of degradation of the investigated colorants increases with the concentration of the ascorbic acid. Namely, when the degradation is followed in the presence of 100 $\mathrm{mg} \mathrm{L}^{-1}$ ascorbic acid, after 21 days more than $85 \%$ of colorants remains in solution (from $86.5 \%$ for tartazine to $93.8 \%$ for brilliant blue FCF). In the presence of $250 \mathrm{mg} \mathrm{L}^{-1}$ ascorbic acid, after 28 days nondegradated colorants are present from $70.5 \%$ for tartazine to $79.2 \%$ for chinoline yellow and brilliant blue. In the model solution with $500 \mathrm{mg} \mathrm{L}^{-1}$ ascorbic acid, the corresponding value ranges from $61.2 \%$ for tartazine to $74.5 \%$ for chinoline yellow. The data for the rate constants are similar to the azo dyes with one naphthalene structure [17]. However, the presence of ascorbic acid increases significantly degradation rate of Brilliant Black BN and Indigotine (Fig. 2). For example, the rate constant for Brilliant Black BN and Indigotine in the presence of $500 \mathrm{mg} \mathrm{L}^{-1}$ of ascorbic acid is 86 or 44 times higher than that for chinoline yellow, respectively (Table 2).

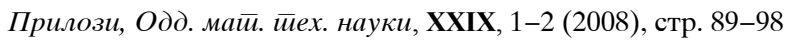




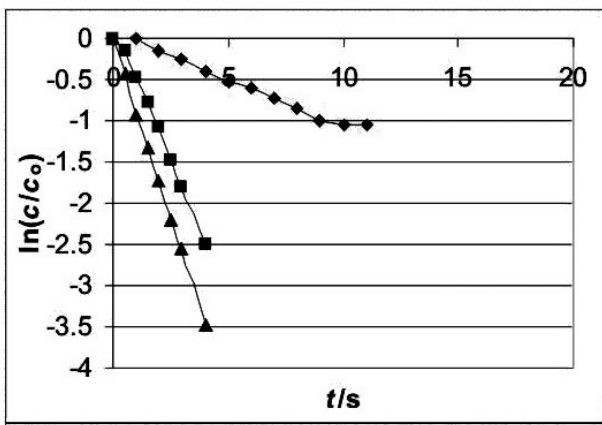

Brilliant Black BN

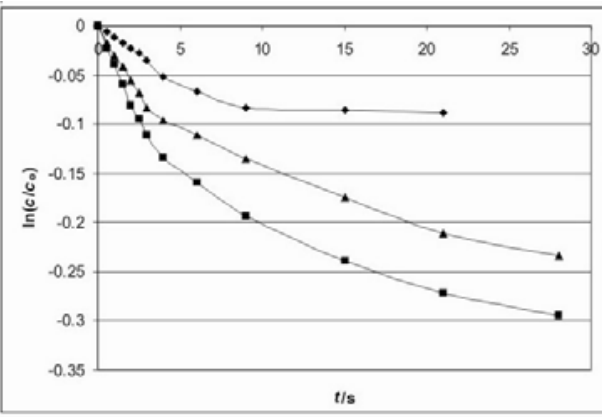

Chinoline Yeloow

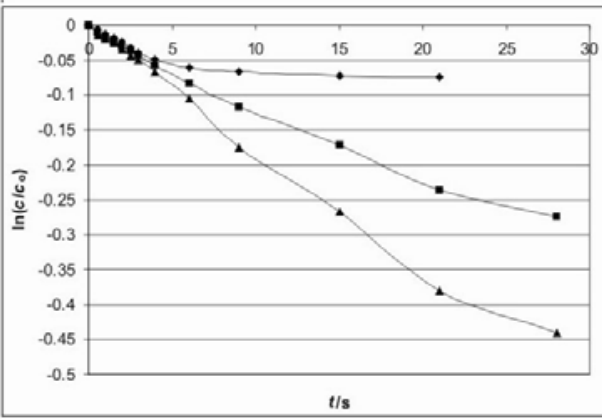

Patent Blue

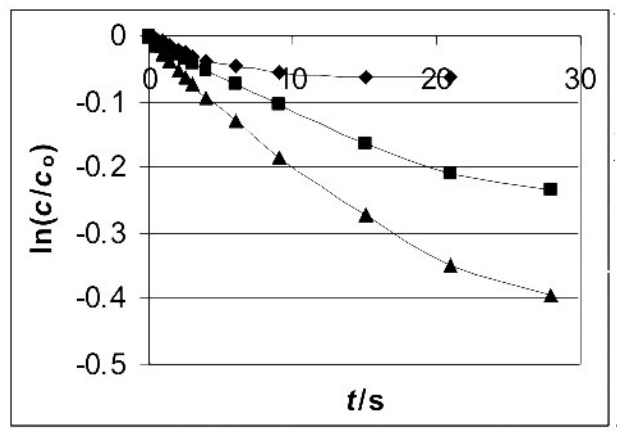

Brilliant Blue

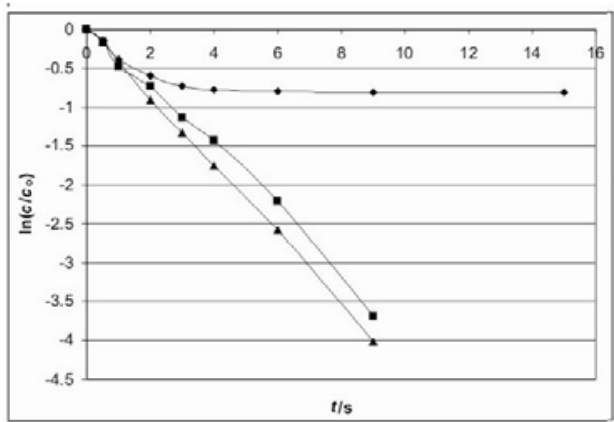

Indigotine

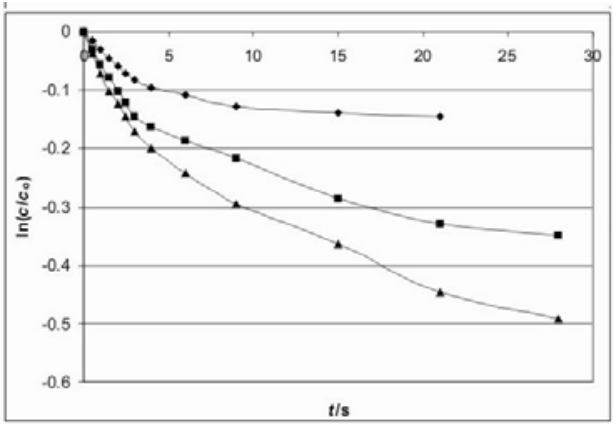

Tartazine

- $100 \mathrm{mg} / \mathrm{L} \mathrm{AA} ;-250 \mathrm{mg} / \mathrm{L} \mathrm{AA} ; \multimap 500 \mathrm{mg} / \mathrm{L} \mathrm{AA}$

Fig. 2. Dependence $\ln \left(c / c_{\mathrm{o}}\right)$ vs. time for the degradation of the investigated food colorants in the presence of $100 \mathrm{mg} / \mathrm{L}, 250 \mathrm{mg} / \mathrm{L}$ and $500 \mathrm{mg} / \mathrm{L}$ of ascorbic acid (AA) 
According to the results for the degradation of investigated food colorants in the presence of various concentrations of ascorbic acid vs. time, rate constant $(k)$, time of the colorants half life $\left(t_{1 / 2}\right)$ and correlation coefficient $(r)$ have been determined (Table 2). The values of the rate constants were calculated from the slopes of the straight lines obtained by plotting $\ln \gamma$ vs. time. This dependence has the form of the linear equation $\left(\ln \gamma=-k t+\ln \gamma_{\mathrm{o}}\right)$ which shows that the plot of $\ln \gamma$ versus $t$ yields a straight line, so the reactions are first order [20].

$\mathrm{T}$ a b 1 e 2

Kinetics of degradation of the synthetic food colorants in the presence of ascorbic acid

\begin{tabular}{|c|c|c|c|c|}
\hline Food colorant & $\gamma\left(\right.$ ascorbic acid) $/ \mathrm{mg} \mathrm{L}^{-1}$ & $k / \mathrm{d}^{-1}$ & $t_{1 / 2} / \mathrm{d}$ & $r$ \\
\hline & 100 & 0.065 & 10.7 & $-0.998^{*}$ \\
\hline \multirow[t]{3}{*}{ Brilliant Black BN } & 250 & 0.64 & 1.1 & -0.999 \\
\hline & 500 & 0.86 & 0.8 & -0.999 \\
\hline & 100 & 0.004 & 157.5 & $-0.992 * *$ \\
\hline \multirow[t]{3}{*}{ Brilliant Blue FCF } & 250 & 0.009 & 78.5 & -0.998 \\
\hline & 500 & 0.015 & 47.1 & -0.999 \\
\hline & 100 & 0.004 & 156.3 & $-0.994 * *$ \\
\hline \multirow[t]{3}{*}{ Chinoline Yellow } & 250 & 0.008 & 87.2 & -0.995 \\
\hline & 500 & 0.010 & 68.7 & -0.999 \\
\hline & 100 & 0.038 & 18.4 & $-0.996 * * *$ \\
\hline \multirow[t]{3}{*}{ Indigotine } & 250 & 0.340 & 2.0 & -0.994 \\
\hline & 500 & 0.440 & 1.6 & -0.992 \\
\hline & 100 & 0.004 & 159.0 & $-0.993 * *$ \\
\hline \multirow[t]{3}{*}{ Pattent Blue V } & 250 & 0.010 & 68.9 & -0.997 \\
\hline & 500 & 0.017 & 41.7 & -0.998 \\
\hline & 100 & 0.006 & 109.3 & $-0.993 * *$ \\
\hline \multirow[t]{2}{*}{ Tartazine } & 250 & 0.012 & 58.9 & -0.996 \\
\hline & 500 & 0.017 & 41.7 & -0.998 \\
\hline
\end{tabular}

* - Values for $r$ are for interval for 4 days

** - Values for $r$ are for interval for 3 days

*** - Values for $r$ are for interval from 0 to 24 hours

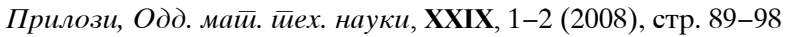


As it can be seen from these results, the rate constant $(k)$ and half-life $\left(t_{1 / 2}\right)$ are higher by increasing the initial concentration of ascorbic acid in the model solution. Correlation coefficients for degradation in the presence of 100 $\mathrm{mg} \mathrm{L}^{-1}$ of ascorbic acid, were calculated for the 3 days (except for Indigotine were it is calculated for $24 \mathrm{~h}$, and for Brilliant Black BN for 4 days) period. The other kinetics parameters $\left(k, t_{1 / 2}\right)$ refer to period of 3 weeks. All parameters for the colorant degradation in the presence of 250 and $500 \mathrm{mg} \mathrm{L}^{-1}$ of ascorbic acid were obtained for the period of 4 weeks.

As it can be seen, the higher concentration of ascorbic acid leads to the higher rate constant and lower colorants half-life. The values of the rate constants are 2.50-4.25 times higher when the colorant degradation was run in the presence of $500 \mathrm{mg} \mathrm{L}^{-1}$ of ascorbic acid than in the case of the presence of 100 $\mathrm{mg} \mathrm{L}^{-1}$ ascorbic acid for Brilliant Blue FCF, Chinoline Yellow, Patent Blue V and Tartazine.

Because of the presence of two azo groups in the structure of Brilliant Black BN, degradation of this colorant is very fast with a total degradation for 6-9 days. Very similar data were obtained for Indigotine probably due to the presence of two NH groups in its structure. Therefore, the rate constants for these two food colorants are much higher than for the other investigated colorants.

\section{REFERENCES}

[1] A. H. Gemeay, Kinetics and mechanism of the reduction of some azo-dyes by inorganic oxysulfur compounds, Dyes Pigments, 54 (2002), 201-212.

[2] J. J. Gooding, R. G. Compton, C. M. Brennan, J. H. Atherton, The mechanism of the electro-reduction of some azo dyes, Electroanalysis, 8 (1996), 519-523.

[3] K. T. Chung, S. E. Stevens, C. E. Cerniglia, The reduction of azo dyes by the intestinal microflora, Crit. Rev. Microbiol., 18 (1992), 175-190.

[4] F. E. Lancaster, J. F. Lawrence, Thermal decomposition of the food colors amaranth, sunset yellow FCF and tartrazine in the presence of sucrose and glucose, Food Addit. Contam., 3 (1986), 295-304.

[5] H. E. Nutsen and G. Williams, The stability of coal tar food colours permitted in the UK, Chem. Ind., 50 (1969), 1798-1802.

[6] E. Poulsen, Safety evaluation of substances consumed as technical ingredients (food additives), Food. Addit. Contam., 8 (1991), 125-133.

[7] E. Poulsen, Case study: erythrosine, Food. Addit. Contam., 10 (1993), 315-323. 
[8] T. F. Collins, T. N. Black, M. W. J. O’Donnel, M. E. Shackelford, P. Bulhack, Teratogenic potential of FD \& C Red No. 3 when given in drinking water, Food Chem. Toxicol., 31 (1993), 161-167.

[9] F. Gosetti, V. Gianotti, S. Angioi, S. Polati, E. Marengo, M. C. Gennaro, Oxidative degradation of food dye E133 Brilliant Blue FCF: Liquid chromatographyelectrospray mass spectrometry identification of the degradation pathway, J. Chromatogr. A, 1054 (2004), 379-387.

[10] M. J. Scotter, L. Castle,_Chemical interactions between additives in foodstuffs: A review, Food Additives and Contaminants, 21 (2004), 93-124.

[11] F. Gosetti, V. Gianotti, S. Polati, M. C. Gennaro, HPLC-MS degradation study of E110 Sunset Yellow FCF in a commercial beverage, J. Chromatogr. A, 1090 (2005), 107-115.

[12] H. Chen, Recent advances in azo dye degrading enzyme research, Curr. Prot. Pept. Sci., 7 (2006), 101-111.

[13] A. H. Gemeay, A.-F. M. Habib, M. A. B. El-Din, Kinetics and mechanism of the uncatalyzed and $\operatorname{Ag}(\mathrm{I})$-catalyzed oxidative decolorization of Sunset Yellow and Ponceau 4R with peroxydisulphate, Dyes Pigments, 74 (2007), 458-463.

[14] 10. A. G. Fogg and A. M. Summan, Further differential-pulse polarographic and visible spectrophotometric studies of the degradation of permitted synthetic food colouring matters with and without the addition of ascorbic acid: degradation in the dark and in the light without the stabilising action of EDTA, Analyst, 108 (1983), 1339-1344.

[15] G. Kroyer, Artificial food colours as food additives. 1. Communication: interaction of artificial food colours with ascorbic acid, Ernahrung, 10 (1986), 392-394.

[16] D. S. Sidhu and J. K. Sudgen, Effect of food dyes on the photostability of aqueous solutions of L-ascorbic acid, Int. J. Pharm. 83 (1992), 263-266.

[17] V. Rizova, T. Stafilov, K. Stojanoski, HPLC investigation of the degradation of some artificial food colorants in the presence of ascorbic acid, Acta Pharm., 49 (1999), 211-216.

[18] V. Rizova, T. Stafilov, XAD-2 HPLC method of indentification and determination of some synthetic colourings, Anal. Lett., 28 (1995), 1305-1316.

[19] L. Marovatsanga, R. Macrae, The determination of added azo dye in soft drinks via its reduction products, Food Chem. 24 (1987), 83-98.

[20] R. Chang, Chemistry, Fifth Edition, McGraw Hill, Inc., Hightstown, 1994, pp. 525 531.

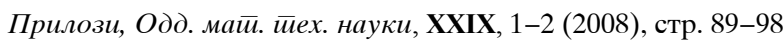


Р е $з$ и м е

\section{НРLС ИСПИТУВАЊА НА ДЕГРАДАЦИЈАТА НА НЕКОИ ВЕШТАЧКИ АЗО ПРЕХРАНБЕНИ БОИ ВО ПРИСУСТВО НА АСКОРБИНСКА КИСЕЛИНА}

Испитувано е влијанието на присуството на аскорбинската киселина на деградацијата на некои вештачки прехранбени азо бои (Brilliant Black BN, Brilliant Blue FCF, Chinoline Yellow, Indigotine, Patent Blue V и Tartazine). Определена е константата на брзината $(k)$ и времето на полураспаѓање $\left(t_{1 / 2}\right)$ на овие бои. Концентрацијата на боите и аскорбинската киселина се определувани со високоефикасна течна хроматографија (HPLC) со детектор со низа од диоди (DAD) и UV-VIS-спектрометрија. Утврдено е дека зголемувањето на концентрацијата на аскорбинската киселина доведува до зголемување на константата на брзината на реакцијата на деградација и до намалување на времето на полураспаѓање на испитуваните бои. Така, утврдено е дека вредностите на константите на брзината на деградација на Brilliant Blue FCF, Chinoline Yellow, Patent Blue V и Tartazine се за 2,50 до 4,25 пати поголеми кога концентрацијата на аскорбинската киселина во растворите е $500 \mathrm{mg} \mathrm{L}^{-1}$ во однос на раствори во кои нејзината концентрација изнесува $100 \mathrm{mg} \mathrm{L}^{-1}$. Деградацијата, пак, на Brilliant Black BN и Indigotine е значително повисока отколку онаа на другите испитувани бои при што нивното целосно разложување настанува за 6-9 дена. Според тоа произлегува дека константата на брзината на деградација на овие две бои е многукратно поголема отколку на другите испитувани бои. Врз основа на линеарноста на кинетичките криви $\left(\ln \left(c / c_{\mathrm{o}}\right.\right.$ од $\left.t\right) \mathrm{e}$ утврдено дека кинетика на деградација на овие бои е од прв ред во периодот до 4 дена.

Клучни зборови: прехранбени бои; Brilliant Black BN; Brilliant Blue FCF; Chinoline Yellow; Indigotine; Patent Blue V; Tartazine; аскорбинска киселина; деградација; кинетичка константа на брзината; HPLC; UV-VIS-спектрометрија

Adress:

Vesna Kostić

Public Health Institute,

POB 577, MK-91001 Skopje, Macedonia

vesna2mk@yahoo.com

\section{Trajče Stafilov}

Institute of Chemistry, Faculty of Science, SS. Cyril and Methodius University, POB 162, MK-91001 Skopje, Macedonia

trajcest@iunona.pmf.ukim.edu.mk

\section{Kiro Stojanoski}

Institute of Chemistry, Faculty of Science, SS. Cyril and Methodius University, POB 162, MK-91001 Skopje, Macedonia

kiro@iunona.pmf.ukim.edu.mk

Received: 28. V 2008

Accepted: 11. IX 2008 